\title{
PENGARUH PERBANDINGAN TEPUNG KETAN PUTIH DENGAN TEPUNG KACANG MERAH (Phaseolus vulgaris L.) TERHADAP KARAKTERISTIK TEMERODOK
}

\author{
Effect of Ratio Glutinous Rice Flour with Red Kidney Bean Flour (Phaseolus vulgaris L.) with on The
}

\author{
Characteristic of Temerodok
}

\author{
Intan Azizah Hs ${ }^{1)}$, Ni Made Yusa ${ }^{2)}$, A.A.I. Sri Wiadnyani ${ }^{2)}$ \\ ${ }^{1)}$ Mahasiswa Jurusan Ilmu dan Teknologi Pangan, Fakultas Teknologi Pertanian, Unud \\ ${ }^{2)}$ Dosen Jurusan Ilmu dan Teknologi Pangan, Fakultas Teknologi Pertanian, Unud \\ Kampus Bukit Jimbaran, Badung-Bali
}

\begin{abstract}
The purpose of the study was to find the optimum ratio of glutinous rice flour and red kidney bean flour (Phaseolus vulgaris L.) to produce temerodok with the best characteristics. The completely randomized design (CRD) was used in the research with treatment that is the ratio of glutinous rice flour with red kidney bean flour which consists of 6 levels: 100\%:0\%,90\%:10\%, 80\%:20\%, 70\%:30\%, 60\%:40\%, 50\%:50\%. The treatment was repeated 3 times to obtain 18 units of the experiment. The data obtained were analyzed by variance and if the treatment had an effect on the observed variable then continued with the Duncan Multiple Range Test (DMRT) test.The ratio of glutinous rice flour and red kidney beans flour has a very significant effect on water content, ash content, protein content, fat content, carbohydrate content, color (scoring), texture (hedonic and scoring), taste (scoring) and significant effect against the levels of crude fiber, color (hedonic), taste (hedonic) and overall acceptance (hedonic). The ratio of glutinous red kidney bean flour (50\%: 50\%) produces the best characteristic temerodok based on the matrix table, namely: water content $5.49 \%, 2.53 \%$ ash content, $15.19 \%$ protein content, fat content $15.46 \%, 61.31 \%$ carbohydrate content, crude fiber content $5.54 \%$, brown color, hard texture, taste very red beans, color, texture, taste and overall acceptancered kidney bean taste and neutral color, texture, taste and and overall acceptability.
\end{abstract}

Keywords : Tradisional food,temerodok, red kidney bean flour, glutinous rice flour.

\section{PENDAHULUAN}

Pangan tradisional adalah pangan yang sudah turun temurun dihasilkan atau dikonsumsi menggunakan bahan yang dihasilkan lokal, diolah secara khas di suatu daerah di Indonesia (Suter, 2014). Temerodok merupakan salah satu pangan atau jajan tradisional dari Pulau Lombok berada di Desa Sakra, Kecamatan Sakra yang mulai dikenal sejak zaman kerajaan Selaparang dan terus dilestarikan sampai sekarang. Temerodok dibuat dari bahan baku tepung ketan dengan bahan tambahan yaitu telur garam dan gula yang memiliki bentuk unik seperti bulan sabit, cita rasa manis, tekstur renyah dan warna agak putih kekuningan (Rabi'ah, 2018)

\footnotetext{
*Korespondensi Penulis:

Email: intanazizahhs96@gmail.com ${ }^{1)}$
}

Temerodok digemari oleh masyarakat Lombok akan tetapi kandungan gizi dari temerodok yang pada umumnya dianggap memiliki nilai gizi yang kurang masyarakat yang mulai beralih ke makanan yang memiliki nilai gizi lebih darijajanan tradisional. Untuk menjadikan temerodok sebagai salah satu jajanan yang memiliki nilai gizi tinggi, maka perlu dilakukan penambahan pangan yang memiliki nilai gizi lebih khususnya protein dan serat, hal ini dilakukan untuk meningkatkan mutu gizi makanan dengan memanfaatkan bahan lokal di daerah setempat, sehingga ketergantungan pada satu bahan pangan dapat dihindari. Salah satu bahan pangan lokal yang bisa digunakan yaitu kacang merah. 
Kacang merah dapat diolah menjadi berbagai macam olahan seperti bubur, lauk pauk, es kacang merah dan bahan isian untuk kue dan tepung. Kandungan gizi dalam 100 g kacang merah kering diantaranya energi $314 \mathrm{kkal}$, protein $22,1 \mathrm{~g}$, lemak 1,1g, karbohidrat 56,2 g, kalsium 502 mg, fosfor $429 \mathrm{mg}$, zat besi $10,3 \mathrm{mg}$, dan vitamin $\mathrm{B}_{1}$ 0,4 mg (Anon., 2005). Selain itu kacang merah juga memiliki kandungan serat sebesar $4 \mathrm{~g}$ dalam per 100g (Afriansyah, 2007).

Menurut Nurlita et al., (2017) penambahan tepung kacang merah $30 \%$ dapat meningkatkan kadar protein pada biskuit tepung kacang merah terbaik yaitu $16,43 \%$ dan penelitian dari Indrastati et al., (2016) melaporkan subsitusi 20\% kacang merah meningkatkan kadar serat snack bar sebesar $23,02 \%$. Penggunaan tepung kacang merah mampu meningkatkan kandungan protein dan serat pada produk pangan. Berdasarkan uraian yang telah dijelaskan sebelumnya maka perlu dilakukan penelitian mengenai pengaruh perbandingan tepung ketan dengan tepung kacang merah terhadap karakteristik temerodok sehingga akan menghasilkan temerodok dengan karakteristik terbaik.

\section{METODE PENELITIAN \\ Tempat dan Waktu}

Penelitian ini dilaksanakan di Laboratorium Analisis Pangan, Laboratorium Pengolahan Pangan, Laboratorium Biokimia dan Nutrisi, serta Laboratorium Rekayasa Proses dan Pengendalian Mutu Fakultas Teknologi Pertanian Universitas Udayana. Pelaksanaan penelitian ini dilakukan pada bulan Oktober sampai dengan bulan November 2018.

\section{Bahan dan Alat}

Bahan-bahan yang digunakan dalam penelitian ini terdiri dari bahan utama, bahan tambahan dan reagen kimia. Bahan utama yaitu, tepung ketan putih (rose brand), Kacang merah varietas jenis Phaseolus dengan ciri diantaranya biji kacang merah berbentuk bulat agak panjang, berwarna merah atau merah berbintik-bintik coklat yang didapat dari supermarket Tiara Dewata, Denpasar. Bahan tambahan yang digunakan dalam pembuatan temerodok meliputi, garam (merek daun), telur ayam dan minyak goreng (tropica) yang didapat dari supermarket Tiara Dewata, Denpasar. Reagen kimia yang digunakan untuk analisis kimia antara lain tablet Kjeldahl, phenolphtalin, asam borat,
$\mathrm{HCl}, \mathrm{NaOH}, \mathrm{H}_{2} \mathrm{SO}_{4}$, aquades, asam sulfat, natrium hidroksida, asam sulfat encer, hexan, vaselin, dan alkohol.

Alat yang digunakan antara lain timbangan analitik, pisau, cetakan bulat untuk menentukan ukuran adonan temerodok, baskom, kompor, ayakan 60 mesh, wajan, sendok, thermometer, tabung gas, loyang, plastik, wadah, blender (Miyako), sarung tangan, gelas ukur (Pyrex), neraca analitik, oven, cawan porselin, alumunium foil, desikator, erlenmeyer (Pyrex), kertas saring (Whatman 42), pipet volume, gelas beaker, pipet tetes, water bath, rolling pin, penggaris, labu ukur, tanur listrik, tabung reaksi (Pyrex), alat kondensor, labu Kjeldahl, dan soxhlet.

\section{Rancangan Percobaan}

Data yang dihasilkan kemudian dianalisis dengan analisis ragam pada program SPSS (Statistical Product and Service Solutions) dan apabila terdapat pengaruh perlakuan terhadap variabel yang diamati, maka dilanjutkan dengan uji Duncan Multiple Rangle Test (DMRT) (Gomez dan Gomez, 1995)

\section{Variabel yang Diamati}

Variabel yang diamati pada penelitian ini yaitu analisis proksimat menurut (Sudarmadji et al., 1997) meliputi kadar air, kadar abu, kadar lemak, kadar protein dan kadar karbohidrat menurut (AOAC, 1990) dan uji sensoris menurut (Soekarto, 1985) yang meliputi warna, tekstur dan penerimaan keseluruhan.

\section{Pelaksanaan Penelitian}

Tahap pelaksanaan penelitian meliputi beberapa tahap yaitu :

a. Persiapan Tepung Kacang Merah

Proses pembuatan tepung kacang merah dimulai dari proses sortasi dan pencucian kacang merah. Kacang merah yang telah disortasi dicuci dengan air yang mengalir. Kacang merah yang telah bersih selanjutnya direbus selama 30 menit setelah air mendidih dengan suhu $90^{\circ} \mathrm{C}$, lalu ditiriskan dan didinginkan. Setelah dingin, kemudian dikeringkan dalam oven bersuhu $60^{\circ} \mathrm{C}$ selama 5 jam. Kacang merah yang telah kering, kemudian dihaluskan dengan menggunakan blender dan diayak dengan ayakan 60 mesh kemudian diperoleh tepung kacang merah (Pangastuti et al., 2013) yang telah dimodifikasi. 
b. Pembuatan Temerodok Kacang Merah

Tahapan pembuatan temerodok yaitu, tepung ketan dan tepung kacang merah ditimbang sesuai dengan perlakuan. Tepung ketan dan tepung kacang merah dicampur, ditambahkan garam $1 \mathrm{~g}$ dan telur $75 \mathrm{~g}$ kemudian semua bahan dicampur hingga homogen dan diuleni hingga adonan kalis. Setiap adonan ditimbang $25 \mathrm{~g}$, adonan dipipihkan sampai tingkat ketebalan $2 \mathrm{~mm}$, adonan dicetak bulat untuk mendapatkan ukuran yang seragam, dibentuk melengkung menggunakan tangan sampai berbentuk bulan sabit kemudian digoreng hingga kering. Proses penggorengan dilakukan pada minyak panas dengan suhu $180^{\circ} \mathrm{C}$ dilakukan selama 3 menit dengan membolak-balik tanpa henti untuk menghasilkan warna putih kecoklatan dan ditiriskan dan dihasilkan temerodok.Adapun formulasi temerodok dapat dilihat pada Tabel 1 .

Tabel 1. Formula temerodok kacang merah

\begin{tabular}{lcccccc}
\hline \multirow{2}{*}{ Komposisi Bahan } & \multicolumn{7}{c}{ Perlakuan } \\
\cline { 2 - 7 } & P0 & P1 & P2 & P3 & P4 & P5 \\
\hline Tepung Ketan Putih (\%) & 100 & 90 & 80 & 70 & 60 & 50 \\
Tepung Kacang Merah (\%) & 0 & 10 & 20 & 30 & 40 & 50 \\
Telur (\%) & 75 & 75 & 75 & 75 & 75 & 75 \\
Garam (\%) & 1 & 1 & 1 & 1 & 1 & 1 \\
\hline
\end{tabular}

\section{HASIL DAN PEMBAHASAN}

Karakteristik kadar air, kadar abu, kadar protein, kadar lemak, kadar karbohidrat, dan kadar serat kasar dari tepung kacang merah yang digunakan dapat dilihat pada Tabel 2 dan hasil analisis bahan baku berdasarkan hasil penelitian dan hasil analisis temerodok kacang merah dapat dilihat pada Tabel 2.

Tabel 2. Nilai rata-rata hasil analisis dari tepung kacang merah

\begin{tabular}{|c|c|c|}
\hline Komponen & Tepung Kacang Merah & Tepung Ketan Putih \\
\hline Air (\%) & $9,78 \pm 0,19$ & 11,55 \\
\hline Abu (\%) & $3,32 \pm 0,11$ & 0,51 \\
\hline Protein $(\%)$ & $21,59 \pm 0,14$ & 6,30 \\
\hline Lemak $(\%)$ & $0,89 \pm 0,04$ & 1,13 \\
\hline Karbohidrat (\%) & $64,40 \pm 1.29$ & 76,24 \\
\hline Serat Kasar (\%) & $3,40 \pm 0,26$ & 0,31 \\
\hline
\end{tabular}

Sumber : Sumber : Singgih et al., (2015) dan Listiyaningrum (2017)

Tabel 3.Nilai rata-rata hasil analisis temerodok kacang merah

\begin{tabular}{lcccccc}
\hline Perlaku an & $\begin{array}{c}\text { Kadar Air } \\
(\% \mathrm{bb})\end{array}$ & $\begin{array}{c}\text { Kadar Abu } \\
(\% \mathrm{bb})\end{array}$ & $\begin{array}{c}\text { Kadar Lemak } \\
(\% \mathrm{bb})\end{array}$ & $\begin{array}{c}\text { Kadar Protein } \\
(\% \mathrm{bb})\end{array}$ & $\begin{array}{c}\text { Kadar } \\
\text { Karbohidrat } \\
(\% \mathrm{bb})\end{array}$ & $\begin{array}{c}\text { Kadar } \\
\text { Serat Kasar }(\% \mathrm{bb})\end{array}$ \\
\hline P0 & $20,46 \pm 0,82 \mathrm{a}$ & $1,19 \pm 0,25 \mathrm{~d}$ & $21,11 \pm 1,74 \mathrm{a}$ & $11,09 \pm 0,63 \mathrm{e}$ & $46,12 \pm 1,74 \mathrm{e}$ & $3,51 \pm 0,60 \mathrm{c}$ \\
P1 & $16,85 \pm 1,39 \mathrm{~b}$ & $1,60 \pm 0,14 \mathrm{c}$ & $19,73 \pm 1,56 \mathrm{~b}$ & $11,83 \pm 0,75 \mathrm{de}$ & $49,96 \pm 1,56 \mathrm{~d}$ & $3,62 \pm 0,79 \mathrm{c}$ \\
P2 & $12,85 \pm 0,31 \mathrm{c}$ & $1,61 \pm 0,12 \mathrm{c}$ & $18,61 \pm 0,74 \mathrm{c}$ & $12,71 \pm 0,70 \mathrm{~cd}$ & $54,19 \pm 0,74 \mathrm{c}$ & $4,18 \pm 0,98 \mathrm{bc}$ \\
P3 & $9,68 \pm 0,31 \mathrm{~d}$ & $1,83 \pm 0,08 \mathrm{~b}$ & $17,75 \pm 1,61 \mathrm{~d}$ & $13,55 \pm 0,94 \mathrm{bc}$ & $57,16 \pm 1,61 \mathrm{~b}$ & $4,56 \pm 0,35 \mathrm{abc}$ \\
P4 & $7,77 \pm 0,67 \mathrm{e}$ & $2,00 \pm 0,04 \mathrm{~b}$ & $16,27 \pm 0,34 \mathrm{e}$ & $14,22 \pm 0,76 \mathrm{ab}$ & $59,87 \pm 0,34 \mathrm{a}$ & $5,02 \pm 0,33 \mathrm{ab}$ \\
P5 & $5,49 \pm 0,60 \mathrm{f}$ & $2,53 \pm 0,16 \mathrm{a}$ & $15,46 \pm 1,52 \mathrm{f}$ & $15,19 \pm 0,88 \mathrm{a}$ & $61,31 \pm 1,52 \mathrm{a}$ & $5,54 \pm 0,80 \mathrm{a}$ \\
\hline
\end{tabular}

Keterangan : Nilai rata - rata yang diikuti oleh huruf yang berbeda pada kolom yang sama menunjukkan berbeda nyata pada Uji Duncan $(\mathrm{P}<0,05)$ 


\section{Kadar Air}

Hasil sidik ragam menunjukkan bahwa perbandingan tepung ketan putih dengan tepung kacang merah berpengaruh sangat nyata $(\mathrm{P}<0,01)$ terhadap kadar air temerodok. Tabel 3 menunjukan kadar air temerodok kacang merah tertinggi diperoleh dari perlakuan P0 yaitu 20,46\% sedangkan kadar air terendah temerodok kacang merah diperoleh dari perlakuan P5 yaitu 5,49\%. Kadar air semakin rendah disebabkan karena semakin tinggi perbandingan tepung kacang merah dapat menurunkan kadar air pada temerodok, hasil analisis bahan baku kadar air pada tepung kacang merah sebesar 9,78\% sedangkan kadar air tepung ketan putih sebesar $11,55 \%$. Hal ini juga bisa disebabkan penyerapan air pada tepung yang dipengaruhi oleh kadar serat dan kadar pati yang tinggi akan semakin kuat menyerap air (Nurani et al., 2014)

\section{Kadar Abu}

Hasil sidik ragam menunjukkan bahwa perlakuan perbandingan tepung ketan putih dengan tepung kacang merah berpengaruh sangat nyata $(\mathrm{P}<0,01)$ terhadap kadar abu temerodok kacang merah. Tabel 3 menunjukkan kandungan kadar abu temerodok kacang merah tertinggi diperoleh dari perlakuan P5 yaitu 2,53\% sedangkan kadar abu terendah diperoleh dari perlakuan P0 yaitu $1,19 \%$. Semakin tinggi perbandingan tepung kacang merah dapat meningkatkan kadar abu pada temerodok. Tingginya kadar abu produk temerodok juga diduga karena kandungan mineral yang terdapat pada tepung kacang merah yang mengandung kadar abu sebesar 3,32\% yang artinya semakin banyak penambahan tepung kacang merah maka semakin tinggi kadar abu temerodok yang dihasilkan. Bogasari (2006) yang menyatakan bahwa semakin tinggi kadar abu maka akan semakin baik, karena kadar abu akan mempengaruhi tingkat kestabilan adonan pada produk pangan

\section{Kadar Lemak}

Hasil sidik ragam menunjukkan bahwa perlakuan perbandingan tepung kacang merah dengan tepung ketan putih berpengaruh sangat nyata $(\mathrm{P}<0,01)$ terhadap kadar lemak temerodok kacang merah. Tabel 3 menunjukkan bahwa nilai rata-rata kadar lemak tertinggi diperoleh pada perlakuan $100 \%$ tepung ketan putih dengan 0\% tepung kacang merah (P0) yaitu $21,11 \%$, sedangkan nilai rata-rata terendah terdapat pada perlakuan $50 \%$ tepung ketan putih dengan tepung kacang merah 50\% (P5) yaitu $15,46 \%$.

Menurunnya kandungan lemak temerodok dikarenakan rendahnya kandungan lemak tepung kacang merah yaitu $0,89 \%$ dan kadar lemak tepung ketan menurut Listiyaningrum (2017) sebesar $1,13 \%$. Lemak merupakan sumber energi bagi tubuh yang dapat memberikan nilai energi lebih besar daripada karbohidrat dan proltein yaitu $9 \mathrm{kkal} / \mathrm{g}$. Lemak juga berfungsi sebagai sumber citarasa dan memberikan tekstur yang lembut pada produk (Winarno, 2004).

\section{Kadar Protein}

Hasil sidik ragam menunjukkan bahwa perlakuan perbandingan tepung ketan putih dengan tepung kacang merah berpengaruh sangat nyata $(\mathrm{P}<0,01)$ terhadap kadar protein temerodok kacang merah. Tabel 3 menunjukkan bahwa nilai rata-rata kadar protein tertinggi diperoleh pada perlakuan $50 \%$ tepung ketan putih dengan 50\% tepung kacang merah (P5) yaitu 15,19\% serta tidak berbeda nyata dengan $\mathrm{P} 4$, sedangkan nilai rata-rata terendah terdapat pada perlakuan $100 \%$ tepung ketan putih dengan $0 \%$ tepung kacang merah (P0) yaitu $11,09 \%$ serta tidak berbeda nyata dengan $\mathrm{P} 2$.

Tingginya kandungan protein pada temerodok dikarenakan kandungan protein tepung kacang merah lebih tinggi dibandingkan tepung ketan putih. Tepung kacang merah mempunyai kadar protein 21,59\% sedangkan tepung ketan sebesar $6,81 \%$, sehingga kadar protein pada temerodok kacang merah meningkat. Beberapa penelitian mengungkapkan bahwa kandungan protein pada kacang-kacangan yang tinggi pada bahan pangan dijadikan sebagai sumber protein.

Menurut Anon (2011) Acuan Label Gizi (ALG) suatu pangan dapat dikatakan sebagai sumber protein jika kadar protein lebih dari $12 \mathrm{~g}$ per $100 \mathrm{~g}$ dalam bentuk padat dengan sasaran konsumen umum. Mengkonsumsi temerodok kacang merah yang dihasilkan pada penelitian ini mampu memberikan kontribusi protein pada makanan.

\section{Kadar Karbohidrat}

Hasil sidik ragam menunjukkan bahwa perlakuan perbandingan tepung ketan putih dengan tepung kacang merah berpengaruh sangat nyata $(\mathrm{P}<0,01)$ terhadap kadar karbohidrat temerodok kacang merah. Tabel 3 menunjukkan kadar 
karbohidrat temerodok kacang merah tertinggi diperoleh dari perlakuan P5 yaitu 61,31\% serta berbeda tidak nyata dengan P4, sedangkan kadar karbohidrat temerodok kacang merah terendah diperoleh dari perlakuan P0 yaitu 46,12\%. Kadar karbohidrat yang dihitung secara by difference dipengaruhi oleh komponen nutrisi lain. Komponen nutrisi yang mempengaruhi besarnya kandungan karbohidrat diantaranya adalah kadar air, abu, protein dan lemak.

\section{Kadar Serat Kasar}

Hasil sidik ragam menunjukkan bahwa perlakuan perbandingan tepung ketan putih dengan tepung kacang merah berpengaruh nyata $(\mathrm{P}<0,05)$ terhadap kadar serat kasar temerodok kacang merah. Tabel 10 menunjukkan bahwa nilairata-rata kadar serat kasar tertinggi diperoleh dari perlakuan 50\% tepung ketan putih dengan 50\% tepung kacang merah (P5) yaitu 5,54\% serta tidak berbeda nyata dengan P3 dan P4, sedangkan kadar serat terendah temerodok kacang merah diperoleh dari perlakuan $100 \%$ tepung ketan putih dengan $0 \%$ tepung kacang merah (P0) yaitu 3,51\% serta tidak berbeda nyata dengan P1 dan P2.

Berdasarkan hasil analisis bahan bahan baku tepung kacang merah mempunyai kadar serat kasar sebesar 3,40\% sedangkan hasil kadar serat kasar tepung ketan $0,31 \%$. Semakin tinggi perbandingan tepung kacang merah dapat meningkatkan kadar serat kasar pada temerodok kacang merah. Kandungan serat yang tinggi pada bahan pangan memiliki manfaat bagi kesehatan tubuh seperti, mengurangi resiko diabetes, menurunkan kadar kolesterol, mencegah wasir, melancarkan buang air besar, mengontrol berat badan dan dapat mencegah kanker kolon (Winarno, 1985). Mengkonsumsi temerodok kacang merah yang dihasilkan pada penelitian ini mampu memberikan kontribusi serat pada makanan, sehingga dengan demikian temerodok yang dihasilkan pada penelitian ini cocok dikembangkan sebagai pangan fungsional.

\section{Evaluasi sensoris}

Evaluasi sensoris temerodok dilakukan dengan uji hedonik terhadap warna, tekstur, rasa dan penerimaan keseluruhan serta uji skoring terhadap warna, rasa dan tekstur temerodok. Nilai rata-rata uji hedonik terhadap warna, tekstur, rasa dan penerimaan keseluruhan temerodok dapat dilihat pada Tabel 4.

Tabel 4. Nilai rata-rata uji sensoris temerodok kacang merah.

\begin{tabular}{|c|c|c|c|c|c|c|c|}
\hline \multirow{3}{*}{ Perlakuan } & \multicolumn{7}{|c|}{ Nilai rata - rata uji hedonik dan uji skor } \\
\hline & \multicolumn{2}{|c|}{ Warna } & \multicolumn{2}{|c|}{ Tekstur } & \multicolumn{2}{|c|}{ Rasa } & \multirow{2}{*}{$\begin{array}{c}\begin{array}{r}\text { Penerimaan } \\
\text { Keseluruhan }\end{array} \\
\mathrm{H}\end{array}$} \\
\hline & $\mathrm{H}$ & S & $\mathrm{H}$ & S & $\mathrm{H}$ & $\mathrm{S}$ & \\
\hline $\mathrm{P} 0$ & $3,80 \mathrm{abc}$ & $1,07 \mathrm{e}$ & $3,00 \mathrm{~d}$ & $2,40 \mathrm{c}$ & $3,80 \mathrm{ab}$ & $1,80 \mathrm{f}$ & $3,27 \mathrm{bc}$ \\
\hline $\mathrm{P} 1$ & $4,47 \mathrm{a}$ & $2,20 \mathrm{~d}$ & $3,40 \mathrm{~cd}$ & $2,60 \mathrm{c}$ & $4,07 \mathrm{a}$ & $2,80 \mathrm{e}$ & $4,00 \mathrm{ab}$ \\
\hline $\mathrm{P} 2$ & $4,07 \mathrm{ab}$ & $3,06 \mathrm{c}$ & $4,67 \mathrm{a}$ & $2,73 \mathrm{c}$ & $4,20 \mathrm{a}$ & $3,47 \mathrm{c}$ & $3,93 \mathrm{ab}$ \\
\hline P3 & $4,20 \mathrm{ab}$ & $3,27 \mathrm{c}$ & $4,40 \mathrm{ab}$ & $3,53 \mathrm{~b}$ & $3,60 \mathrm{ab}$ & $3,93 \mathrm{~b}$ & $4,27 \mathrm{a}$ \\
\hline $\mathrm{P} 4$ & $3,47 \mathrm{bc}$ & $4,07 \mathrm{~b}$ & $3,93 \mathrm{bc}$ & $4,06 \mathrm{ab}$ & $3,47 \mathrm{ab}$ & $4,73 \mathrm{a}$ & $3,40 \mathrm{bc}$ \\
\hline P5 & $3,13 \mathrm{c}$ & $4,80 \mathrm{a}$ & $3,40 \mathrm{~cd}$ & $4,46 \mathrm{a}$ & $3,00 \mathrm{~b}$ & $4,87 \mathrm{a}$ & $3,00 \mathrm{c}$ \\
\hline
\end{tabular}

Keterangan : Nilai rata - rata yang diikuti oleh huruf yang berbeda pada kolom yang sama menunjukkan berbeda nyata pada Uji Duncan $(\mathrm{P}<0,05)$.

- H (Hedonik) Nilai Hedonik: 1 (tidak suka), 2 (agak tidak suka), 3 (biasa ) 4 (agak suka), 5 (suka)

-S (Skoring) Nilai skoring warna 1 (putih); 2 (putih kecoklatan); 3 (coklat keputihan); 4 (cokelat)

; 5 (Coklat kemerahan)

Nilai skoring tekstur :1(tidak renyah); 2 (agak renyah); 3 (renyah), 4 (sangat renyah ). Nilai skoring rasa: 1(tidak terasa kacang merah); 2 (agak terasa kacang merah); 3 (terasa kacang merah); 4 (sangat terasa kacang merah) 


\section{Warna}

Hasil sidik ragam menunjukkan bahwa perlakuan perbandingan tepung ketan putih dengan tepung kacang merah berpengaruh nyata $(\mathrm{P}<0,05)$ terhadap uji hedonik dan perpengaruh sangat nyata terhadap uji skoring warna . Nilai rata-rata uji hedonik warna temerodok pada Tabel 4 berkisar antara 3,13 (agak suka) sampai dengan 4,47 (suka) serta berbeda tidak nyata dengan P1 dan P3, sedangkan nilai rata-rata terendah diperoleh pada perlakuan 50\% tepung ketan putih dan 50\% tepung kacang merah (P5) yaitu 3,13 (biasa) serta berbeda tidak nyata dengan $\mathrm{P} 0$ dan $\mathrm{P} 4$.Sedangkan uji skor warna temerodok diperoleh pada perlakuan 50\% tepung ketan putih dan 50\% tepung kacang merah (P5) yaitu 4,80 (cokelat), sedangkan nilai rata-rata terendah diperoleh pada perlakuan $100 \%$ tepung ketan putih dan $0 \%$ tepung kacang merah $(\mathrm{P0})$ yaitu 1,06 (putih)

Berdasarkan uji hedonik panelis lebih menyukai warna (hedonik) temerodok dengan perlakuan P1 (90\% tepung ketan putih dan 10\% tepung kacang merah) yaitu 4,47 (agak suka) sedangkan untuk uji skroing nilai tertinggi diperoleh pada P5 yaitu 4,80 (cokelat kemerahan).

\section{Tekstur}

Hasil sidik ragam pada menunjukkan bahwa perbandingan tepung ketan putih dengan tepung kacang merah berpengaruh sangat nyata $(\mathrm{P}<0,01)$ terhadap uji hedonik dan berpengaruh sangat nyata $(\mathrm{P}<0,01)$ terhadap uji skor tekstur temerodok. Tabel 4 menyatakan bahwa tingkat nilai rata-rata tertinggi kesukaan panelis terhadap tekstur temerodok diperoleh pada perlakuan $90 \%$ tepung ketan putih dan 20\% tepung kacang merah (P2) yaitu 4,67 (agak suka) serta berbeda tidak nyata dengan P3, sedangkan nilai rata-rata terendah diperoleh pada perlakuan $100 \%$ tepung ketan putih dan $0 \%$ tepung kacang merah (P0) yaitu 3,00 (biasa) serta berbeda tidak nyata dengan P1,P4 dan P5.

Berdasarkan uji skor temerodok kacang merah yang memiliki nilai rat-rata tertinggi diperoleh pada perlakuan 50\% tepung ketan putih dan 50\% tepung kacang merah (P5) yaitu 4,46 (sangat renyah) serta tidak berbeda nyata dengan P4. Sedangkan nilai terendah diperoleh pada perlakuan $100 \%$ tepung ketan dan $0 \%$ tepung kacang merah (P0) yaitu 2,40 (agak renyah) serta tidak berbeda nyata dengan P1,P2 dan P3. Pada penelitian ini, hasil uji hedonik tekstur panelis paling menyukai tekstur temerodok pada perlakuan $70 \%$ tepung ketan putih dan $30 \%$ tepung kacang merah (P3) karena produk yang dihasilkan mempunyai tekstur yang renyah sedangkan berdasarkan uji skoring tekstur temerodok tertinggi diperoleh pada P5 yaitu 4,46 (sangat renyah).

\section{Rasa}

Hasil sidik ragam menunjukkan bahwa perbandingan tepung ketan putih dengan tepung kacang merah berpengaruh nyata $(\mathrm{P}<0,05)$ terhadap uji hedonik dan berpengaruh sangat nyata $(\mathrm{P}<0,01)$ terhadap uji skor rasa temerodok. Tabel 4 menunjukkan bahwa Nilai rata-rata tingkat kesukaan panelis terhadap rasa di uji hedonik temerodok berkisar antara 3,00 (biasa) sampai 4,20 (agak suka). Sedangkan nilai rata-rata tertinggi terhadap uji skor rasa temerodok tertinggi diperoleh pada perlakuan $50 \%$ tepung ketan putih dan $50 \%$ tepung kacang merah (P5) yaitu 4,87 (sangat terasa kacang merah) dan nilai rata-rata terendah temerodok diperoleh pada perlakuan $100 \%$ tepung ketan putih dan $0 \%$ tepung kacang merah (P0) yaitu 1,80 (tidak terasa kacang merah).

Seiring dengan penggantian yang semakin tinggi antara tepung kacang merah dengan tepung ketan putih maka temerodok yang dihasilkan akan semakin terasa kacang merah. Terlepas dari komponen lainnya (warna dan tekstur), rasa merupakan faktor penting yang menentukan daya terima suatu produk pangan. Rasa yang enak dapat menarik perhatian konsumen untuk lebih menyukai makanan.

\section{Penerimaan Keseluruhan}

Hasil sidik ragam menunjukkan bahwa perbandingan tepung kacang merah dengan tepung ketan putih berpengaruh nyata $(\mathrm{P}<0,05)$ terhadap penerimaan keseluruhan temerodok. Tabel 4 menyatakan bahwa nilai rata-rata berkisar antara 3,00 (biasa) sampai 4,27 (agak suka). Tingkat kesukaan panelis terhadap penerimaan keseluruhan temerodok diperoleh pada perlakuan $70 \%$ tepung ketan putih dan 30\% tepung kacang merah (P3) yaitu 4,27 (agak suka) serta berbeda tidak nyata dengan $\mathrm{P} 1$ dan $\mathrm{P} 2$, Sedangkan nilai rata-rata terendah diperoleh pada perlakuan $50 \%$ tepung ketan putih dan $50 \%$ tepung kacang merah (P5) yaitu 3,00 (biasa) serta berbeda tidak nyata dengan $\mathrm{P} 0$ dan P4. Penerimaan keseluruhan temerodok dipengaruhi oleh beberapa faktor seperti warna, tekstur dan rasa. Namun secara keseluruhan, temerodok kacang merah masih dapat diterima oleh panelis. 


\section{KESIMPULAN DAN SARAN \\ Kesimpulan}

Berdasarkan hasil penelitian ini dapat

disimpulkan sebagai berikut :

1. Perbandingan tepung ketan putih dengan tepung kacang merah berpengaruh sangat nyata terhadap kadar air, kadar abu,kadar protein, kadar lemak, kadar karbohidrat, warna (skoring), tekstur (hedonik dan skoring), rasa (skroing) dan berpengaruh nyata terhadap kadar serat kasar, warna (hedonik), rasa (hedonik) dan penerimaan keseluruhan (hedonik)

2. Perlakuan perbandingan $50 \%$ tepung ketan putih dengan 50\% tepung kacang merah menghasilkan temerodok karakteristik

\section{DAFTAR PUSTAKA}

Afriansyah, N. 2007. Kacang merah turunkan kolesterol dan gula darah (http://www.fmipa.ipb.ac.id) diakses: 29 Agustus 2018

Anonimus .2011. Peraturan Kepala Badan Pengawas Obat dan Makanan Nomor HK.03.1.23.11.11.09657 tentang Persyaratan Penambahan Zat Gizi dan zat Non Gizi dalam Pangan Olahan. Jakarta : Badan POM RI.

Anonimus. 1996. Syarat Mutu Kerupuk Beras SNI 01-4307-1996. Badan Standarisasi Nasional. Jakrata

Anonimus. 1998. Syarat Mutu Tepung Ketan. Standar Nasional Indonesia SNI 014447- 1998. Badan Standarisasi Indonesia. Jakarta

Anonimus. 2005. Daftar Komposisi Bahan Makanan. Departemen Kesehatan, Jakarta

Astawan, M. 2009. Sehat dengan Hidangan Kacang dengan Biji-biji. Penebar Swadaya, Jakarta

Bogasari, 2006. Referensi Terigu. http://www.bogasari.com/refillourthm. Diakses pada tanggal 5 Mei 2019

Buckle, K.A., R.A. Edwards, G.H. Fleet, dan M. Wooton. 1987. Food Science (Terjemahan Ilmu Pangan). UI Press. Jakarta

Gomez, K.A., dan A.A. Gomez. 1995. Prosedur Statistik untuk Penelitian Pertanian. Diterjemahkan oleh: E. Sjamsuddin dan J.S. Baharsjah. UI Press, Jakarta. terbaik berdasarkan tabel matrik yaitu: kadar air $5,49 \%$, kadar abu $2,53 \%$, kadar protein $15,19 \%$, kadar lemak $15,46 \%$, kadar karbohidrat $61,31 \%$, kadar serat kasar $5,54 \%$, warna cokelat, tekstur keras, rasa sangat terasa kacang merah, warna, tekstur, rasa dan penerimaan keseluruhan biasa.

\section{Saran} untuk :

Berdasarkan hasil penelitian ini disarankan

1. Sebaiknya dilakukan penelitian lebih lanjut mengenai umur simpan dari temerodok kacang merah.

2. Dilakukan penelitian lebih lanjut mengenai perbandingan ketan putih dengan menggunakan tepung kacang jenis lainnya.

Haslina. Fatima, S.M dan Suyatno. 2006. Nilai gizi, daya cerna protein dan daya terima patilo sebagai makanan jajanan yang diperkaya dengan hidrolisat protein ikan mujair (Oreochromis mossambicus). Jurnal Gizi Indonesia. 1(2): 37-38.

Indrastati, N., dan G. Anjani. 2016. Snack bar kacang merah dan tepungumbi garut sebagai alternatif makanan selingan dengan indek glikemik rendah. 5 (4) : 546-554

Listiyaningrum, P.F. 2017. Optimasi peningkatan gluten pada tepung beras dalam upaya perbaikan kualitas adonan tepung beras. Skripsi. Tidak Dipublikasikan. Institut Pertanian Bogor, Bogor.

Ketaren, S. 2008. Pengantar Teknologi Minyak dan Lemak Pangan. Universitas Indonesia, Jakarta

Ningrum, M.R.B. 2012. Pengembangan Produk cake dengan Stubtitusi Tepung Kacang Merah. Skripsi. Tidak Dipublikasikan. Universitas Negeri Yogyakarta, Yogyakarta.

Nurani, S. dan S. S. Yuwono. 2014. Pemanfaatan tepung kimpul (Xanthosoma sagittifolium) sebagai bahan baku cookies (kajian proporsi tepung dan penambahan margarin). Jurnal Pangan dan Agroindustri.2(2) : 50- 58.

Nurlita, H, dan N. Asyik. 2017. Pengaruh penambahan tepung kacang merah (plaseolus vulgaris l.) dan tepung labu kuning (cucurbita moschata) terhadap penilaian organoleptik dan nilai gizi biskuit. Sains dan Teknologi Pangan. 2(3): 562-574. 
Pangastuti, H. A., D. R. Affandi, dan D. Ishartati. 2013. Karakterisasi sifat fisik dan kimia tepung kacang merah (phaseolus vulgaris l.) dengan beberapa perlakuan. Jurnal Teknosains Pangan. 2 (1) : (20-29)

Rabi'ah, B. 2018. Wawancara: Pedagang Temerodok. Desa Sakra, Kecamatan Sakra, Lombok.

Rahmat, R. 2009. Buncis. Kanisius, Yogyakarta Rusilanti,. C. M. Kusharto. 2007. Sehat dengan Makanan Berserat. Agromedia Pustaka, Jakarta.

Simamora. F.M. 2016. Kajian Konsentrasi Tepung Kacang Merah dan Tepung Tempe Terhadap Kualitas Daging Analog. Skripsi. Tidak Dipublikasikan. Universitas Pasundan, Bandung
Singgih. W.D dan Harijino. 2015. Pengaruh subtitusi proposi tepung beras ketan dengan kentang pada pembuatan wingko. 3 (4) : 1573-1583

Soekarto, S.T. 1985. Penilaian Organoleptik untuk Industri Pangan dan Hasil Pertanian. Pusat Pengembangan Teknologi Pangan IPB, Bogor

Sudarmadji, S.B, Haryono dan Suhardi. 1989. Analisa Bahan Makanan dan Pertanian. Penerbit Liberty. Yogyakarta.

Suter, K.I. 2014. Pangan Tradisional : Potensi dan prospek pengembangannya. 1 (1) : 96-109

Winarno, F.G. 2004. Kimia Pangan dan Gizi. Gramedia. Jakarta 